\title{
The Thickness Effect of Exothermic Sleeve Made From Rice Husk on Its Performance as A Riser in Steel Casting
}

\author{
Wiwik Purwadi, Dewi Idamayanti *, Beny Bandanadjaja, Muhammad Zanet, Muhammad Rizki \\ Gorbyandi Nadi \\ Foundry Engineering, Politeknik Manufaktur Bandung, Jl. Kanayakan No 21 Dago Bandung 40135, Indonesia \\ idamayanti79@gmail.com
}

\begin{abstract}
Exothermic sleeves are useful to be applied in the steel foundry for minimizing the size of the riser and increasing its efficiency. This paper describes the effect of the thickness of the exothermic sleeves made of rice husk and the modulus of the riser to the feeding efficiency of riser for the casting of metal. The series of thermal analysis of carbon steel (GS20Mn5) under the conditions of various thicknesses of exothermic sleeve at the same modulus and various geometry modulus of the riser at the same thickness of sleeve were carried out. Direct Thermal analysis of the cooling rate of the riser was conducted for the temperature during the cooling down to the solidus temperature were conducted. Based on the cooling curves, Modulus Extension Factors as an indicator of the effectiveness of the exothermic sleeves were determined and compared. By comparing the cooling rates, it was found that a $25 \mathrm{~mm}$ thick sleeve produced the highest MEF value (1.90) for the riser modulus of $1.6 \mathrm{~cm}$ and a solidification time of 285 seconds. Riser modulus of $1 \mathrm{~cm}$ produces MEF value of 1.90 , which is higher than the modulus of $1.6 \mathrm{~cm}$ and $3 \mathrm{~cm}$ at the sleeve thickness of $15 \mathrm{~mm}$
\end{abstract}

Key words : Casting of metal, Exothermic sleeves, modulus the riser, Rice husk,

\section{INTRODUCTION}

\subsection{Feeding}

The main problem in the steel foundry industry is the low yield of casting products (under 50\% on average) since riser is to be used to compensate for the relatively large shrinkage of around 7\% [1]. During the solidification process of liquid metal in the mold, shrinkage may occur in the product due to temperature changes. The liquid metal becomes solid by experiencing three stages of shrinkage, namely liquid shrinkage, crystal shrinkage, and solid shrinkage (solid shrinkage) [2]. Hardin et al. said that increasing the efficiency and modulus of the riser can be done by increasing the solidification time [3], which is understood as the cooling time between pouring temperature and solidification temperature. A sleeve is a material that covers the liquid in the riser and provides longer solidification time so as to provide a liquid supply for the purpose of feeding.

\subsection{Potential of rice husk as a sleeve}

Based on how it works, the exothermic sleeve must be made of a material that is easily flammable or has exothermic properties when exposed to metal liquid. Materials that have these properties are carbonaceous materials and thermite materials [4]. Carbonaceous materials are organic materials with a very high amount of carbon content. While thermite materials are flammable materials that release an amount of heat in a short time. Based on this, Idamayanti et al. [5] conducted research on the substitution material of exothermic sleeve using rice husk material. This material has a calorific value of $15.3 \mathrm{~kJ} /$ gram, which is higher than that of a typical exothermic sleeve with a value of $11.35 \mathrm{~kJ} /$ gram [5]. Exothermic rice husk sleeve is able to extend the solidification rate from 215 to 454 seconds. The modulus extension factor (MEF) obtained from exothermic rice husk is 1.69. This value meets the minimum requirement of MEF value based on Indian Standard IS 15865: 2009, which is 1.60 [6]. Idamayanti et al [5] showed that the Modulus Extension Factor (MEF) value of the rice husk sleeve was still below the MEF value of the primarily produced exothermic sleeve

Rice husk is an abundant amount of biomass in an agrarian country. Biomass itself is a kind of material derived from living things that can be renewed in a relatively short time [7]. As biomass, rice husk has a huge hydrocarbon content of around 44\%, as shown in Table 1 [8]. The hydrocarbon content can furthermore be used as fuel to provide the required heat. The higher the carbon content of a material, the more energy (heat) the material can produce. Rice husk has a fuel value of around $3000-3600 \mathrm{Kcal} / \mathrm{kg}$, Fuel value is the number of calories that is produced by the material.

This level of fuel value enables rice husk to be defined as exothermic material [9]. The refractory nature of rice husks 
depends on their alkaline oxide content. But normally it can withstand temperatures up to $1600^{\circ} \mathrm{C}$. Rice husks are porous and lightweight, with a bulk density of around $210-300 \mathrm{~kg} /$ $\mathrm{m} 3[9]$.

Table 1 : Elemental Test Results on Rice Husk [8]

\begin{tabular}{|c|c|c|c|c|c|c|}
\hline LOI & \multicolumn{7}{|c|}{ Element, \%s } \\
\hline $\begin{array}{c}\text { Carbon } \\
\text { (organic) }\end{array}$ & $\mathbf{N}$ & $\mathbf{F e}$ & $\mathbf{A l}$ & $\mathbf{M g}$ & $\mathbf{S i}$ & $\mathbf{K}$ \\
\hline 38.69 & 0.67 & 0.0055 & 0.0070 & 0.051 & 6.82 & 0.36 \\
\hline
\end{tabular}

\subsection{Thermophysical calculation}

According to Joseph Black theory, if there is a mixing of two substances, the amount of heat released by the substance with higher temperature is equal to the amount of heat received by the substance with lower temperature [10]. Since casting processes to deal with higher temperatures, the amount of the heat energy produced is proportional to the mass of the sleeve and its specific heat. Differences in the size of the sleeve caused dissimilarity subsequently in the mass of liquid metal, which at the end will affect the amount of energy received by the sleeve itself. This will also affect the cooling/solidification rate that occurs in the casting process. The cooling rate is defined as the function of heat absorbed or released by objects against other surrounding objects that have differences in temperature with time [11]. The greater heat received by the sleeve will affect the duration of the cooling process.

The geometry modulus of the riser, as well as of casting, is used to determine the location of the riser in the casting design. Modulus is a function of the solidification rate of an object and is defined as the volume (V) of the object divided by the area of the heat releasing section (A). When the modulus of the object is getting bigger, more liquid metal is available so that the cooling/solidification process takes longer. Based on this, the greater the modulus, the slower the cooling [12]. According to its thermal properties, the sleeve is divided into 3 types: exothermic, insulating, and exothermic-insulating sleeve [2].

Sleeve thickness is one of the factors that greatly affect the performance of the sleeve. The use of sleeves with a thickness of $15 \%$ of the diameter of the riser and the use of hot toppings on the top of riser produce a flat shrinkage form [12]. The increased efficiency of the riser is caused by the slowing down of the cooling rate due to the higher thickness of the sleeve.

\subsection{Characterization}

Modulus extension factor (MEF) is the ratio of the geometrical modulus of the sand riser and the geometric modulus of the sleeved riser [6] so that the sleeved riser is considered to have the same modulus as the sand riser modulus. The thickness and modulus of the exothermic sleeve have a great influence on the MEF value of the sleeve, which is normally assessed based on the solidification rate of the riser [6].

Therefore this research was conducted by measuring and analyzing the solidification rate of the riser sleeve and calculating MEF at various modulus and thickness. The effects of these on the thermophysical properties of the exotherm sleeves are then to be observed.

\subsection{Research aim}

This study is aimed to analyze the effect of different modulus and thickness on the thermophysical properties of the rice husk exothermic sleeve and to produce a rice husk exothermic sleeve that meets the sleeve standard specifications of the Indian standard [6].

\section{2. DESIGN OF EXPERIMENT}

\subsection{Sleeve material and casting material}

Sleeve in this study has a composition of 60 mesh rice husk as much as $89 \%, 11 \%$ of polyvinyl acetate as a binder, and methanol as much as $180 \%$ of the amount of polyvinyl acetate. Methanol is used as thinner for the polyvinyl acetate. When methanol is mixed with polyvinyl acetate, this polymer will stabilize and form a surfactant, which act as an active substance on the surface of the solution, so that it will adsorb strongly at the liquid and air interface [13]. The material used in this study is GS30Mn5.

\subsection{Sleeve shape and dimension}

This study uses a tubular sleeve with 3 modulus variations, which are $1 \mathrm{~cm}, 1.6 \mathrm{~cm}$, and $3 \mathrm{~cm}$, with a height and diameter ratio of 1: 1. Based on the IS 15865:2009 [6], the riser diameter (D) is five times the modulus (M). Then the diameter of the sleeve for MEF testing is $50 \mathrm{~mm}, 80 \mathrm{~mm}$, and $150 \mathrm{~mm}$.

To determine the effect of the thickness of the exthermic sleeve on the riser, an experiment with two variations of thickness of $15 \mathrm{~mm}$ and $25 \mathrm{~mm}$ on a riser with a modulus of $1.6 \mathrm{~cm}$ was also carried out (Figure 1).
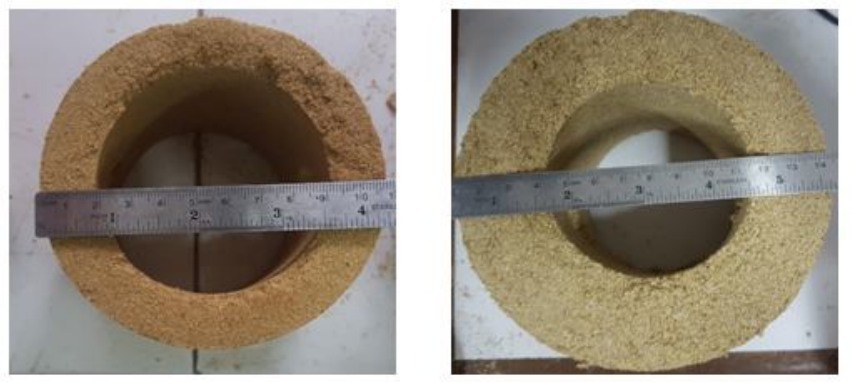

Figure 1: The exothermic sleeve of modulus 1.6 with 2 a thickness of $15 \mathrm{~mm}$ and $25 \mathrm{~mm}$ 


\subsection{Casting}

The liquid GS $30 \mathrm{Mn} 5$ steel was poured at a temperature of $1600 \mathrm{oC} \pm 20 \mathrm{oC}$ into the alcaly phenolic mold. Prior to the pouring exothermic sleeves were inserted into the mold. To ensure uniform condition of each trial gating system, as shown in Figure 2, is used. Rice husk is compacted to produce the desired tubular shape and dimension with a constant bulk density of 0.60195 gr.cm-3.

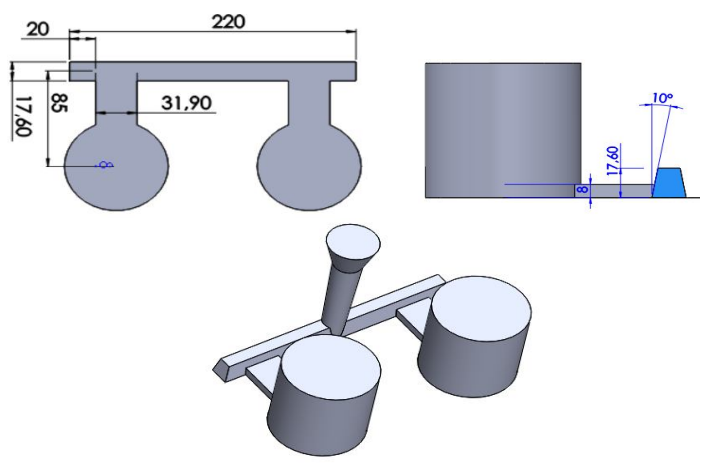

Figure 2 : Gating system of casting

\subsection{Characterization}

To analyze the results of this study, calculation of modulus extension factor (MEF) and Feeding Safety Margin (FSM) is used.

\section{A. Determination of Modulus Extension Factor (MEF)}

Modulus extension factor (MEF) is the effective ratio of the sand riser and riser sleeve. MEF values are determined by comparing the modulus of the sleeved riser with the modulus of the sand riser by using the solidification rate $[6,12]$. If a riser with an exothermic sleeve that has a geometry modulus of $\mathrm{A} \mathrm{cm}$ demonstrates the same cooling rate as a sand riser that has a geometry modulus of $\mathrm{B} \mathrm{cm}$, then $\mathrm{MEF}$ is determined as the $\mathrm{B} / \mathrm{A}$ ratio. MEF value is calculated by comparing the solidification rate on the riser sleeve and sand riser as described in the Indian Standard.

Simplified procedure to determine the MEF value, as suggested by Ignaszak and Prunier, was conducted [14]. The first step is to measure the solidification rate of the rice husk riser sleeve. Temperature measurement is carried out in the range between the pouring temperature and solidus temperature of the material so that the delay time of the solidification can be observed. The temperature detection and measurement were carried out directly on the riser sleeve by using a data logger and thermocouple type R. The measurement position shown in Figure 3 refers to William's research [15].

The solidification rate of the sand riser is obtained through a casting simulation using the SolidCast 8.2.5 application, whereby the data of temperatures was retrieved from the thermocouples, which was positioned as shown in Figure 3.
To determine the solidus temperature of the material, the $\mathrm{Fe}-\mathrm{Fe}$ 33C phase diagram is used. Since GS30Mn5 steel material is classified as low alloy steel, a carbon equivalent (CE) value is applied in the phase diagram instead of just carbon content. Following is the formula determining the value of $\mathrm{CE}[16]$.

$$
C E=C+\frac{S i}{38}+\frac{M n}{6}+\frac{N i}{12}+\frac{C r}{1,8}+\frac{M o}{2,3}+\frac{C u}{9,1}
$$

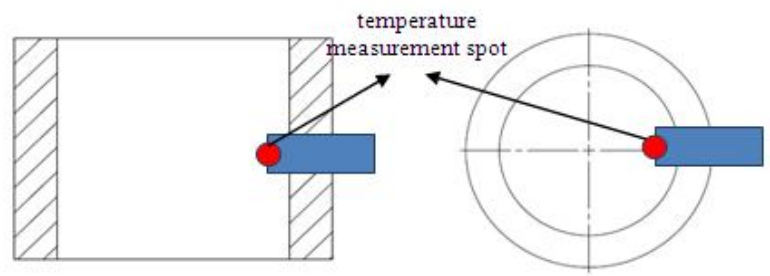

Figure 3 : Measuring temperature at the riser

Based on the composition of the material that has been determined bu applying Optical Emission Spectrometry (OES), the CE value of $0.69 \%$ was obtained. According to $\mathrm{Fe}-\mathrm{Fe} 3 \mathrm{C}$ diagram and the formula derived by Miettinen and Howe, the liquidus temperature is therefore $1490^{\circ} \mathrm{C}$, and solidus temperature is $1400^{\circ} \mathrm{C}$ [17].

\section{B. Feeding efficiency of a plate casting (plate test)}

Volumetric feed efficiency of a sleeve is defined as the percentage of maximum feed metal transferred to the casting during its solidification at the same level of feed safety margin as found in a sand riser of given dimensions mounted on the same casting. The feed efficiency is obtained by calculating the percentage of feed metal supplied to the casting relative to a sand riser [6].

Feed safety margin (FSM) is the safe limit for liquid supply from a riser to casting. FSM is measured based on the distance between the lowest shrink surface of a riser to the bottom of the riser. FSM value is determined by applying a cube test [6].

\section{RESULTS AND DISCUSSION}

\subsection{Determination Modulus Extension Factor (MEF)}

MEF values were obtained by analyzing the solidification/cooling rate of the sleeved riser and sand riser. The following are the MEF values on various thickness and modulus.

\section{A. Determination Modulus Extension Factor (MEF) at various thickness}

The solidification rate test was carried out on various thicknesses of the sleeve on the riser with a diameter of 80 $\mathrm{mm}$ (modulus $1.6 \mathrm{~cm}$ ). The cooling rate of GS30Mn5 steel was also observed for the sleeve thickness of $15 \mathrm{~mm}$ and 25 $\mathrm{mm}$. Figure 4 confirms that the thickness of the sleeve affects the cooling rate of the metal, where the sleeve with a thickness 
of $25 \mathrm{~mm}$ has a temperature retarding time longer than a sleeve with a thickness of $15 \mathrm{~mm}$ and a sand riser.

The considered working area of a riser is above the solidus line. Therefore the determination of the riser modulus is done by measuring the solidification time of the material up to its solidus point.

Table 2 and Figure 4. Temperature retarding time of riser sleeve up to solidus point. Show the difference in holding time up to the solidus point (freezing time) for each variation. A sleeve with a thickness of $25 \mathrm{~mm}$ has the largest working area of 285 seconds, a sleeve with a thickness of $15 \mathrm{~mm} 188$ seconds, and a sand riser of 21 seconds.

Both types of the sleeve have a much larger working area compared to the sand riser, which proves that sleeved riser can perform longer feeding time and more supply of fluid than a sand riser [12].

Figure 4 described the cooling rates of the sand riser, riser sleeve with a thickness of $15 \mathrm{~mm}$ and $25 \mathrm{~mm}$. Riser sleeves with a thickness of $15 \mathrm{~mm}$ indicate a considerably constant temperature during the cooling process at the temperature of $1460^{\circ} \mathrm{C}$ for up to 120 seconds. Riser sleeve with a thickness of $25 \mathrm{~mm}$ experiences a significant increase in temperature from the pouring temperature to a temperature of $1610^{\circ} \mathrm{C}$, and then it will be followed by a constant decrease starting from 120th second. The graph shows that the heat rate is proportional to the change in temperature with time. It can be seen that riser sleeve with a thickness of $15 \mathrm{~mm}$ has a lower cooling rate compared to riser sleeve with a thickness of 25 $\mathrm{mm}$ by $1 / 5$ times. $15 \mathrm{~mm}$ riser can be considered as slightly better at releasing heat compared to the $25 \mathrm{~mm}$ riser.

The amount of heat supply is very influential on the temperature of the material. The variation of thickness causes, therefore, a change of the cooling rate of GS30Mn5. Sleeve with a thickness of $25 \mathrm{~mm}$ has a mass of 450 grams, and a sleeve thick 15 has a mass of 235 grams.

Cooling Rate of Sleeve at Various Thickness

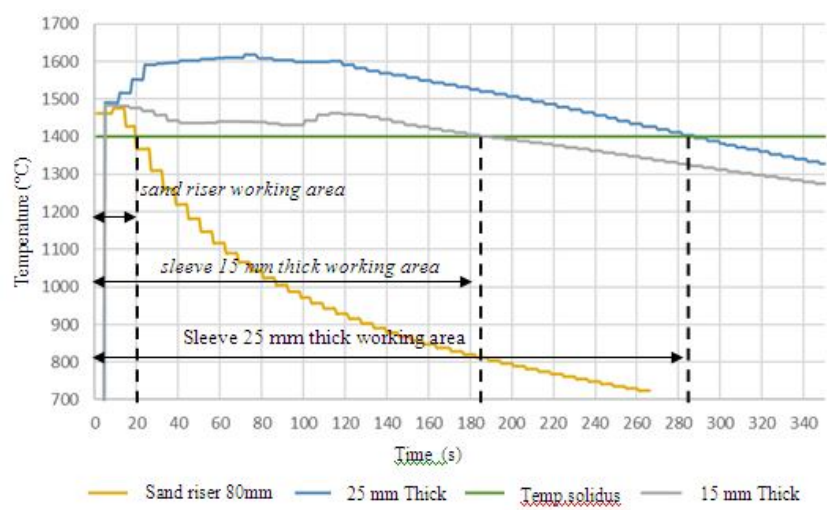

Figure 4 : Temperature retarding time of riser sleeve up to solidus point
The heat produced by each sleeve is determined by its mass and can be calculated as follows

$$
\begin{aligned}
& Q=m \cdot c \cdot \Delta T, \mathrm{sC} \\
& Q 15 \text { thick }=m \cdot c \cdot \Delta T=\frac{235}{1000} g r x 1690,71 \frac{J}{K g K} x(1460-1400)=23,84 J \\
& \mid Q 25 \text { thick }=m \cdot c \cdot \Delta T=\frac{450}{1000} \operatorname{gr} x 1690,71 \frac{\mathrm{J}}{\mathrm{KgK}} x(1610-1400)=159,77 \mathrm{~J} \mid \\
& \text { note : } \quad \mathrm{Q}=\text { Heat (Joule) } \\
& \mathrm{m}=\text { Mass of sleeve }(\mathrm{kg}) \\
& \mathrm{c} \quad=\text { Specific heat of rice husk } \\
& (\text { Joule/Kg.K) }=1690,71 \mathrm{~J} / \mathrm{Kg}[18] \\
& \Delta \mathrm{T}=\text { Temperature difference }\left({ }^{\circ} \mathrm{C}\right)
\end{aligned}
$$

Table 2 : Ratio sleeve mass to mass of liquid metal

\begin{tabular}{|c|c|c|}
\hline No. & Type of Riser & Solidification time \\
\hline 1 & Sand riser & 21 seconds \\
\hline 2 & Riser with $15 \mathrm{~mm}$ thick sleeve & 190 seconds \\
\hline 3 & Riser with $25 \mathrm{~mm}$ thick sleeve & 285 seconds \\
\hline
\end{tabular}

Based on the above calculations, the amount of heat produced by a sleeve of $25 \mathrm{~mm}$ thick is $159,77 \mathrm{~J}$ while a sleeve of $15 \mathrm{~mm}$ thick produces only $23,84 \mathrm{~J}$. The temperature of GS30Mn5 steel in the sleeved riser with a sleeve thickness of 25 has a higher increase compared to the sleeved riser with a sleeve thickness of $15 \mathrm{~mm}$. During the cooling process of the GS30Mn5, which is wrapped with a $25 \mathrm{~mm}$ thick sleeve receives a very large amount of heat energy so that the cooling process will be longer though the relatively similar heat rate. MEF is obtained from the ratio of the solidification rate between the sleeved riser and sand riser. Table 3 presents the sand riser solidification time data, as resulted from the SolidCast 8.2.5 software simulation.

The solidification time required for the material to reach the solidus temperature by the $15 \mathrm{~mm}$ thick sleeve (196 seconds) is relatively similar to those of the $140 \mathrm{~mm}$ sand riser (190 seconds). Since the riser of $25 \mathrm{~mm}$ thick sleeve is associated with a greater supply of heat compared to a riser with $15 \mathrm{~mm}$ thick sleeve, in the term of solidification time, it is only comparable with a sand riser of $152 \mathrm{~mm}$ diameter (Table 4).

Table 3 : Solidification time of sand riser

\begin{tabular}{|c|c|c|c|}
\hline No. & Diameter (mm) & Modulus (cm) & $\begin{array}{c}\text { Solidication } \\
\text { time (s) }\end{array}$ \\
\hline 1 & 80 & 1.6 & 21 \\
\hline 2 & 136 & 2.72 & 163 \\
\hline 3 & 140 & 2.8 & 196 \\
\hline 4 & 152 & 3.04 & 255 \\
\hline 5 & 156 & 3.12 & 271 \\
\hline 6 & 160 & 3.2 & 317 \\
\hline
\end{tabular}


Wiwik Purwadi et al., International Journal of Emerging Trends in Engineering Research, 8(8), August 2020, 4777-4783

Table 4 : Solidification time of riser with $15 \mathrm{~mm}$ thick sleeve, the sand riser of $140 \mathrm{~mm}$ diameter, riser with $125 \mathrm{~mm}$ thick sleeve and sand riser of $156 \mathrm{~mm}$ diameter

\begin{tabular}{|c|c|c|c|}
\hline No. & Riser Type & $\begin{array}{c}\text { Mod } \\
\text { ulus }\end{array}$ & $\begin{array}{c}\text { Solidication } \\
\text { time (s) }\end{array}$ \\
\hline 1 & Riser with 15mm sleeve & 1.6 & 190 seconds \\
\hline 2 & Sand riser 140mm diameter & 2.8 & 196 seconds \\
\hline 3 & Riser with $25 \mathrm{~mm}$ sleeve & 1.6 & 285 seconds \\
\hline 4 & Sand riser $152 \mathrm{~mm}$ diameter & 3.04 & 280 seconds \\
\hline
\end{tabular}

Based on the comparison of the solidification time of the two risers, the MEF values of the $15 \mathrm{~mm}$ thick sleeve and $25 \mathrm{~mm}$ thick sleeve are as follows

MEF of riser with $15 \mathrm{~mm}$ thick sleeve $=\frac{2,8}{1,6}=1,75$

MEF of riser with $25 \mathrm{~mm}$ thick sleeve $=\frac{3,04}{1,6}=1,90$

For the purpose of a comparative study Idamayanti et al. has conducted MEF testing on the Kalminex sleeve riser used in POLMAN Bandung [5]. Based on his research, the Kalminex sleeve riser has a MEF of 1.77. Figure 5 shows that a riser wrapped with a $15 \mathrm{~mm}$ thick rice husk sleeve generates a MEF value of 1.75 , which is slightly below the MEF value of Kalminex sleeve (1.77). The riser with a rice husk sleeve of 25 $\mathrm{mm}$ thick generates a MEF value of 190, respectively. This proves that the increasing thickness of the sleeve can expand the MEF value since it produces a higher amount of heat to compensate for the decreasing temperature during the solidification process.

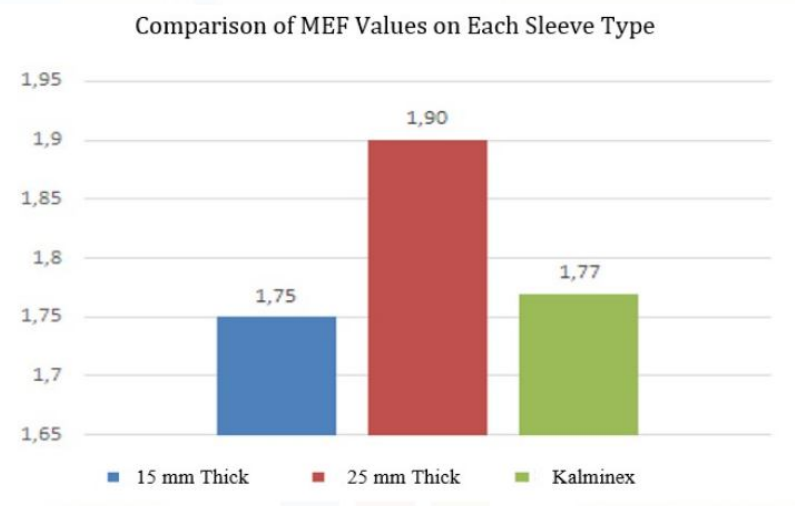

Figure 5 : MEF value of sleeves

\section{B. Modulus Extension Factor (MEF) fo various modulus}

The solidification rate test was carried out on three types of sleeved risers with a variation of modulus, which was $1 \mathrm{~cm}$, $1.6 \mathrm{~cm}$, and $3 \mathrm{~cm}$ with the same sleeve thickness of $15 \mathrm{~mm}$. Riser sleeve with a diameter of $50 \mathrm{~mm}$ (modulus $1 \mathrm{~cm}$ ), 80 $\mathrm{mm}$ (modulus $1.6 \mathrm{~cm}$ ) and $150 \mathrm{~mm}$ (modulus $3 \mathrm{~cm}$ ) has a solidification time in the following sequence: 48 seconds, 190 seconds and 434 seconds. Riser sleeves with larger modulus consequently have longer solidification time [12] due to a more significant mass of liquid.

As previously discussed, MEF of a riser sleeve with a modulus of $1.6 \mathrm{~cm}$ (diameter 80 ) is 1.75 . The MEF value is obtained from the ratio of the sleeve solidification rate to the sand riser solidification rate. Table 5 presents the sand riser solidification times resulted from the SolidCast 8.2.5 software simulation.

Table 5 : Solidification time of sand riser

\begin{tabular}{|c|c|c|c|}
\hline No. & $\begin{array}{c}\text { Diameter } \\
(\mathbf{m m})\end{array}$ & Modulus (cm) & $\begin{array}{c}\text { Solidication time } \\
(\mathbf{s})\end{array}$ \\
\hline 1 & 90 & 1.8 & 39 \\
\hline 2 & 95 & 1.9 & 50 \\
\hline 3 & 240 & 4.8 & 408 \\
\hline 4 & 244 & 4.88 & 431 \\
\hline
\end{tabular}

Table 6 : Retarding time of sleeved riser modulus $1 \mathrm{~cm}$ dan sand riser $95 \mathrm{~mm}$

\begin{tabular}{|c|c|c|c|}
\hline $\begin{array}{c}\text { N } \\
\text { o. }\end{array}$ & Riser Type & Modulus & $\begin{array}{c}\text { Retarding } \\
\text { Time }\end{array}$ \\
\hline 1 & $\begin{array}{c}\text { Sleeved Riser modulus } \\
1 \mathrm{~cm}\end{array}$ & $1.0 \mathrm{~cm}$ & 48 seconds \\
\hline 2 & Sand riser $95 \mathrm{~mm}$ & $1.9 \mathrm{~cm}$ & 50 seconds \\
\hline 3 & $\begin{array}{c}\text { Sleeved riser modulus } \\
3 \mathrm{~cm}\end{array}$ & $3 \mathrm{~cm}$ & 434 seconds \\
\hline 4 & Sand riser $244 \mathrm{~mm}$ & $4.88 \mathrm{~cm}$ & 431 seconds \\
\hline
\end{tabular}

The solidification rate lines of the sleeved riser with a geometry modulus of $1 \mathrm{~cm}$ and the sand riser with a diameter of $95 \mathrm{~mm}$ intersect the solidus temperature line at almost the same time. Likewise, the solidification rate lines of the sleeved riser with a modulus of $3 \mathrm{~cm}$ intersect the solidus temperature line at almost the same time as the solidification rate line of the sand riser with a diameter of $244 \mathrm{~mm}$. Based on these, the MEF value of the sleeved riser with a modulus of $1 \mathrm{~cm}$ is 1.9 , and the sleeved riser of the modulus $3 \mathrm{~cm}$ is 1.63 .

MEF values of rice husk sleeved riser in various modulus exceed the minimum MEF value, as stated in the Indian Standard, which is 1.60 [16]. At the same sleeve thickness, increasing the modulus of the riser decreases the MEF value. A higher modulus can be understood as an increase in the liquid mass, which means that the amount of heat to be supplied is also increasing. However, the MEF value continues to decline. This is caused by the amount of liquid that needs to be supplied by the sleeve, where the greater the geometric modulus of the sleeve, the greater the amount of liquid that needs to be supplied. So the ratio between the weight of the sleeve and the weight of the liquid becomes smaller, as shown in Table 7. 
Wiwik Purwadi et al., International Journal of Emerging Trends in Engineering Research, 8(8), August 2020, 4777-4783

Table 7 : Ratio sleeve mass to mass of liquid metal

\begin{tabular}{|c|c|c|c|c|c|}
\hline No. & $\begin{array}{c}\text { Riser } \\
\text { Type }\end{array}$ & $\begin{array}{c}\text { Diamet } \\
\text { er }\end{array}$ & $\begin{array}{c}\text { Mass of } \\
\text { Sleeve (S) }\end{array}$ & $\begin{array}{c}\text { Mass of } \\
\text { liquid } \\
\text { metal }\end{array}$ & $\begin{array}{c}\text { Ratio } \\
\text { S/G }\end{array}$ \\
\hline 1 & $\begin{array}{c}\text { Modulu } \\
\text { s 1cm }\end{array}$ & $50 \mathrm{~mm}$ & $113 \mathrm{gram}$ & $0.77 \mathrm{~kg}$ & 0.14 \\
\hline 2 & $\begin{array}{c}\text { Modulu } \\
\text { s } 1.6 \mathrm{~cm}\end{array}$ & $80 \mathrm{~mm}$ & $235 \mathrm{gram}$ & $3.14 \mathrm{~kg}$ & 0.07 \\
\hline 3 & $\begin{array}{c}\text { Modulu } \\
\text { s 3cm }\end{array}$ & $150 \mathrm{~mm}$ & $699 \mathrm{gram}$ & $20.68 \mathrm{~kg}$ & 0.03 \\
\hline
\end{tabular}

As shown in Table 7 that the same sleeve thickness of $15 \mathrm{~mm}$ creates a less mass ratio of rice husk and liquid metal for higher modulus. The amount of rice husk mass that is aimed to supply liquid metal with exothermic heat per kilogram of the liquid becomes smaller. The increasing modulus of riser causes, therefore, a decrease in MEF value subsequently.

\section{Morphology of solidification curve of the sleeved riser}

The morphology of the solidification rate comes out mainly in two types. The characteristics of these graphs show the reaction or phenomenon that occurs in the riser during the solidification and cooling process.

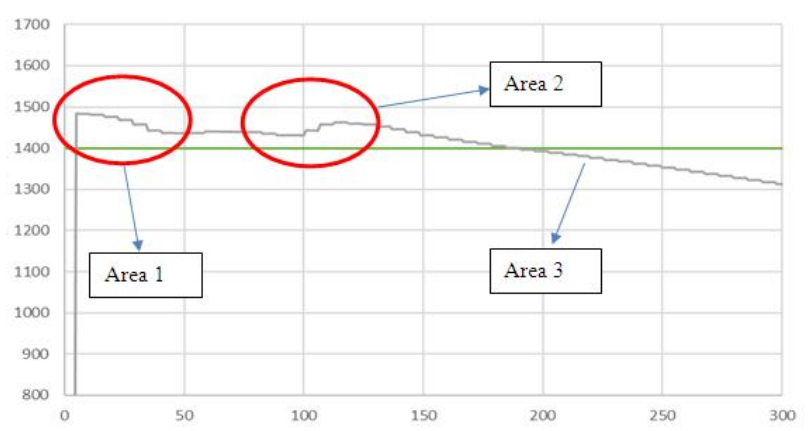

(a)

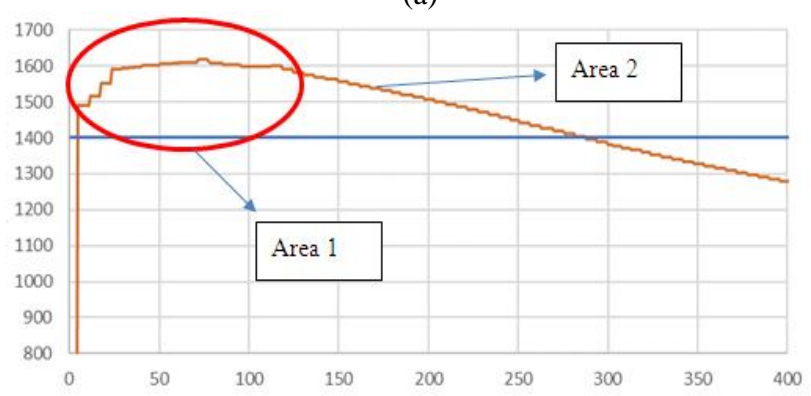

(b)

Figure 6 : Solidification and cooling curves of rice husk sleeved riser

The first graphical characteristics, as shown in Figure 6(a), are formed during the cooling process of the rice husk sleeves with a diameter of the riser of 80 and 150 and a sleeve thickness of $15 \mathrm{~mm}$. It describes that there are three different working areas. Suharto [7] explains that rice husks may experience two times exothermic reactions, namely the pyrolysis reaction and the oxidation reaction [7]. Area 1 is the area where the first exothermic reaction occurs, which is the pyrolysis reaction. Pyrolysis combustion reaction may occur even in the absence of oxygen from the adjacent environment because rice husks already have oxygen as a constituent element itself. This reaction causes the cooling rate to be slower than without the sleeve. Area 2 After the pyrolysis reaction occurs, a few moments later, an oxidation reaction or combustion takes place. At this stage, a reaction occurs between biomass, charcoal, and pyrolysis products. This reaction is exothermic so as to produce adequate heat and cause a temperature surge, as shown in the graph. Area 3 is where all of the reaction has completely finished so that at this stage, only a consistent temperature decrease occurs.

The second type of cooling curve is shown in Figure 6(b). This graph is remarked with just two working areas. Area 1 on the riser with a sleeve thickness of $25 \mathrm{~mm}$ does not indicate clearly the occurrence of two reactions. There is a combustion process in area 1, whereas, according to Suharto [7], rice husks experience two exothermic reactions. This is caused by the thickness of the burning sleeve so that the pyrolysis and oxidation reactions do not occur at the same time. The pyrolysis reaction takes place gradually and alternately with the oxidation reaction causing a rise in temperature simultaneously and significantly, as shown in the graph. In area 2, the exothermic reaction is completed. Some applications and integration can be considered for further exploration [19] [20].

\section{CONCLUSION}

The thicker the sleeve at the same geometry modulus of the riser, the more heat is produced during the burning of the sleeve, and the solidification time becomes longer. Sleeve with a thickness of $25 \mathrm{~mm}$, the longest solidification time of 285 seconds. Increasing the geometry modulus of the rice husk sleeved riser at the same sleeve thickness will decrease the MEF value of the riser since the amount of heat to be supplied gets intensified. By applying various thicknesses, the rice husk sleeve produces the highest MEF value at a sleeve thickness of $25 \mathrm{~mm}$ with a MEF value of 1.90. The rice husk sleeve that produces the highest MEF value is a sleeve with a modulus of $1 \mathrm{~cm}$ with a MEF value of 1.90 , while risers with higher geometry modulus at the same sleeve thickness of 25 mm produce lower MEF value.

\section{ACKNOWLEDGEMENT}

Hibah PTUKK Polman Bandung funded this research. All authors acknowledge to Polman Bandung for funding and all facilities

\section{REFERENCES}

1. T. A. Burns. The Foseco foundryman's handbook: facts, figures and formulae, Elsevier, 2017.

2. A. S. M. Handbook. Volume 15 Casting, Materials Park: ASM International, pp. 416-522, 2008. 
3. R. A. Hardin, T. J. Williams, and C. Beckermann. Riser sleeve properties for steel castings and the effect of sleeve type on casting yield, 67th SFSA Technical and Operating Conference, Chicago, IL, USA, 2013.

4. P. N. Rao. Manufacturing Technology (fourth) Vol.1, India: McGraw Hill Education, 2013.

5. D. Idamayanti, W. Purwadi, and B. Bandanadjaja. Rice husk waste as exothermic material for riser sleeve in steel casting, IJTECH, (on Reviewed), vol. 11, no.1. pp. 71-80, 2020.

6. The Foundry and Steel Castings Sectional Committee. Exothermic and Insulating Sleeves for Use in Foundries, Bureau of Indian Standard IS 15865, 2009.

7. Suharto. Kajian Awal Potensi Pemanfaatan Biomassa Sekam Padi Untuk Pembangkit Listrik Melalui Teknologi Gasifikasi Di Provinsi Sulawesi Selatan, Seminar Nasional Kimia Dan Pendidikan Kimia V, vol.3, no.6, pp. 434-442, 2013.

8. Q. Lu, X. L. Yang, and X. F. Zhu. Analysis on chemical and physical properties of bio-oil pyrolyzed from rice husk, Journal of Analytical and Applied Pyrolysis, vol. 82, no. 2, pp. 191-198, 2008.

https://doi.org/10.1016/j.jaap.2008.03.003

9. P. C. Kapur. Thermal Insulations from Rice Husk Ash, An Agricultural Waste, Ceramurgia International, vol.6, no.2, pp. 75-78, 1980. https://doi.org/10.1016/0390-5519(80)90045-9

10. R. Resnick, and D. Haliday. Fisika Jilid I (Terjemahan). Jakarta: Penerbit Erlangga, 1987.

11. P. G. Hewitt. Conceptual physics, Pearson Educación, 2002.

12. R. Wlodawer. Directional Solidification of Steel Castings, in Directional Solidification of Steel Castings, 1966. https://doi.org/10.1016/c2013-0-01798-7

13. S. M. Sulistyoningsih. Sintesis Perekat Polivinil Asetat Berbasis Pelarut Metanol Yang Terstabilkan oleh
Disponil, Doctoral Dissertation, Institut Teknologi Sepuluh Nopember, Surabaya, 2014.

14. Z. Ignaszak, and J. B. Prunier. Innovative Laboratory Procedure to Estimate Thermophysical Parameters of Iso-exo Sleeves, Archives of Foundry Engineering, vol.17, no.1, pp.67-72, 2017.

15. T. J. Williams. Determination of effective riser sleeve thermophysical properties for simulation and analysis of riser sleeve performanc, Recommended Citation (University of Lowa), 2016.

16. T. Kasuya, Y. Hashiba. Carbon equivalent to assess hardenability of steel and prediction of HAZ hardness distribution, SHINNITTETSU GIHO, 385, 48, 2006.

17. J. Miettinen, A. A. Howe. Estimation of liquidus temperatures for steels using thermodynamic approach, Ironmaking \& Steelmaking, vol. 27, no. 3, pp. 212-227, 2000.

18. P. Kalita, M. J. Clifford, K. Jiamjiroch, K. Kalita, P. Mahanta, U. K. Saha. Characterization and analysis of thermal response of rice husk for gasification applications, Journal of Renewable and Sustainable Energy, vol.5, no.1, pp.13119, 2013.

19. Nguyen, V.-V., Pham, T.-K., Tran, H.-B. Evaluation of response modification factor of multiple story steel buildings, International Journal of Emerging Trends in Engineering Research 8(4), pp. 1342-1348, 2020. https://doi.org/10.30534/ijeter/2020/66842020

20. Cherney, O.T., Smirnova, Z.V., Semakhin, E.A., Kutepova, L.I. Steel microstructure after thermal and chemo-thermal reprocessing of steel, International Journal of Emerging Trends in Engineering Research 8(6),2, pp. 2229-2232, 2020. https://doi.org/10.30534/ijeter/2020/02862020 